\title{
Artesunate inhibits lung cancer cells via regulation of mitochondrial membrane potential and induction of apoptosis
}

\author{
YAN ZHAO $^{1}$, JIANGHUI LIU ${ }^{2}$ and LIANG LIU ${ }^{2}$ \\ Departments of ${ }^{1}$ Otolaryngology and Head and Neck Surgery and ${ }^{2}$ Flow Cytometry Analysis, \\ Tumor Institute, The Fourth Hospital of Hebei Medical University, Shijiazhuang, Hebei 050011, P.R. China
}

Received January 10, 2020; Accepted June 26, 2020

DOI: $10.3892 / \mathrm{mmr} .2020 .11341$

\begin{abstract}
Lung cancer is a common malignant disease with a high incidence rate worldwide, posing a great threat to human health. To date, only a small number of studies have assessed the potential anti-cancer effect of artesunate (Art) and the associated mechanisms in lung cancer. The present study aimed to investigate the inhibitory effects of Art in human lung cancer cells and investigated the underlying molecular mechanisms. The inhibitory effect of Art on the growth of A549 lung cancer cells was detected by the MTT assay, and flow cytometry was utilized to determine cell cycle progression, apoptosis, mitochondrial membrane potential, as well as the expression of Bcl-2 and Bax proteins in A549 cells after Art treatment for $24 \mathrm{~h}$. Art inhibited the growth of A549 cells in a dose-dependent manner, induced cell apoptosis and cell cycle arrest, decreased the expression of $\mathrm{Bcl}-2$ protein and mitochondrial membrane potential, and increased the expression of Bax protein. In conclusion, Art significantly inhibited the growth of lung cancer cells by preventing cell cycle progression. This phenomenon indicated its promising therapeutic potential in the treatment of lung cancer.
\end{abstract}

\section{Introduction}

Lung cancer is a common malignancy and its initiation and progression are complex processes associated with the loss of normal regulatory pathways, including cell proliferation, differentiation and apoptosis (1-4). Current treatment strategies include chemotherapy; however, the efficacy is limited and the side effects of these drugs pose major challenges (5). Therefore, the development of novel lung cancer drugs is imperative. Owing to its long history in tumor treatment, the

Correspondence to: Professor Liang Liu, Department of Flow Cytometry Analysis, Tumor Institute, The Fourth Hospital of Hebei Medical University, 12 Jiankang Road, Shijiazhuang, Hebei 050011, P.R. China

E-mail: aliangdaziran@163.com

Key words: lung cancer, artesunate, cell apoptosis, cell cycle, flow cytometry search for anti-tumor drugs among Chinese herbal medicines has become a hot topic in cancer research.

Artesunate (Art) is a water-soluble hemisuccinate derivative of dihydroartemisinin and the most widely used member of the family of artemisinin drugs. Artemisinin compounds are widely used for the treatment of severe and complicated malaria in humans. Art is a classic anti-malarial drug for the treatment of severe and drug-resistant malaria (6-10). It also exerts anti-tumor activity (11-17). Several in vitro and in vivo studies have indicated that the anti-tumor effect of Art is associated with the induction of apoptosis and cell cycle arrest (11-13). It was also demonstrated to inhibit tumor infiltration and metastasis $(18,19)$. However, studies investigating the mechanisms of the anti-tumor effects of Art in lung cancer are limited, and hence, its role in lung cancer therapy remains to be clarified. In the present study, the anti-cancer efficacy of Art in the A549 lung adenocarcinoma cell line was assessed and the underlying molecular mechanisms were investigated.

The balance between apoptosis and cell proliferation is essential for maintaining the function of normal cells and growth of normal tissues $(20,21)$. Disruption of this balance leads to diseases, including tumors, in the body. Cell apoptosis is closely linked to the occurrence of a tumor. At present, apoptosis is the most studied mechanism in anti-cancer therapy. Cellular apoptosis is an automated gene-controlled death program mediated via complex regulatory mechanisms. Bcl-2, Bax and the mitochondrial membrane potential are essential effectors of the intrinsic pathway of apoptosis.

In the present study, it was investigated whether Art is able to induce lung cancer cell apoptosis by regulating the intrinsic apoptosis pathway, thereby providing a novel Art-mediated mechanism for lung cancer treatment.

\section{Materials and methods}

Cell line and culture. The human lung cancer cell line A549 was purchased form Procell Life Science \& Technology Co., Ltd., and cultured in RPMI 1640 medium supplemented with $10 \%$ fetal bovine serum (both purchased from Gibco; Thermo Fisher Scientific, Inc.), 100 units $/ \mathrm{ml}$ penicillin and $100 \mu \mathrm{g} / \mathrm{ml}$ streptomycin at $37^{\circ} \mathrm{C}$ in a humidified atmosphere with $5 \% \mathrm{CO}_{2}$.

Chemicals and reagents. Art was purchased from Guilin Pharmaceutical (Shanghai) Co., Ltd. The Annexin V-FITC/PI 
kit was purchased from Beckman Coulter, Inc., while propidium iodide (PI) was purchased from BD Biosciences.

Cytotoxicity assay. The sensitivity of A549 lung cancer cells to Art was determined using an MTT assay, which is based on the capacity of viable cells to metabolize a yellow tetrazolium salt, MTT, to form purple formazan crystals. These are solubilized in acidified 2-propanol and the absorbance is measured spectrophotometrically at $490 \mathrm{~nm}$. The cells were seeded in 96-well plates at a density of $5 \times 10^{4}$ cells $/ \mathrm{ml} /$ well. Once cells were attached, serially diluted art solution was added to reach a final concentration of $0,0.1,0.5,1,5,10,50,100,200,400$ or $800 \mu \mathrm{g} / \mathrm{ml}$ in a final volume of $200 \mu \mathrm{l} /$ well. Normal saline (NS) was used for the control group (22). After drug treatment for $24 \mathrm{~h}$, the medium was replaced with an equivalent volume of fresh RPMI 1640 medium containing $0.5 \mathrm{mg} / \mathrm{ml} \mathrm{MTT \text {, }}$ followed by incubation for an additional $4 \mathrm{~h}$. Subsequently, the medium was replaced with $180 \mu \mathrm{l} \mathrm{DMSO}$, followed by incubation for $10 \mathrm{~min}$ at room temperature. The cytotoxic effects of the drug concentrations were determined by measuring the optical density values at $490 \mathrm{~nm}$ with a microplate reader. Cell viability was expressed as the relative synthesis of formazan in treated samples compared with the control cells [(treated cells/control cells) x100\%].

Experimental groups and drug intervention experiments. After the cultured A549 tumor cells were attached, cells were grouped evenly and treated with serial concentrations of artesunate $(0,25,50$ and $100 \mu \mathrm{g} / \mathrm{ml})$ for $24 \mathrm{~h}$. Then, cells were harvested routinely; NS was used as the control. The cell concentration of the suspension was adjusted to $1 \times 10^{6} / \mathrm{ml}$. Each experiment was performed three times.

Assessment of the cell cycle distribution using flow cytometry $(F C M)$. Single-cell suspension $\left(1 \mathrm{ml}\right.$ containing $1 \times 10^{6}$ cells $)$ was prepared, washed with cold PBS and fixed with $70 \%$ ethanol at $4^{\circ} \mathrm{C}$ for $24 \mathrm{~h}$ prior to the addition of $1 \mathrm{ml} \mathrm{PI}$ $(50 \mu \mathrm{g} / \mathrm{ml})$. After incubation at $4^{\circ} \mathrm{C}$ for $30 \mathrm{~min}, \mathrm{FCM}$ (FC-500; Beckman Coulter, Inc.) was performed and MultiCycle AV software (Beckman Coulter, Inc.) was used to analyze the cell cycle. The proliferation status was expressed by the following proliferation index $=\left(S+G_{2} / M\right) /\left(G_{0} / G_{1}+S+G_{2} / M\right) \times 100 \%$.

Assessment of cell apoptosis of A549 cells using FCM. To detect apoptosis, $1 \mathrm{ml}$ of single-cell suspension was stained with PI $(12.5 \mu \mathrm{g} / \mathrm{ml})$ and Annexin V-FITC $(0.25 \mu \mathrm{g} / \mathrm{ml})$ and analyzed with an FC500 flow cytometer (Beckman Coulter). Cells with positive staining for Annexin $\mathrm{V}$ and negative staining for PI were considered to be in early apoptosis, whereas those that were positive for both Annexin V and PI were considered to be in late apoptosis.

Analysis of mitochondrial membrane potential of A549 cells using FCM. To determine the mitochondrial membrane potential following Art treatment, harvested A549 cells were washed with ice-cold PBS and stained with $1 \mathrm{ml}$ fluorescence reagent containing $10 \mu \mathrm{g} / \mathrm{ml}$ Rhodamine 123 . After incubation for $30 \mathrm{~min}$ in the dark at $37^{\circ} \mathrm{C}$, the stained cells were re-suspended in $1 \mathrm{ml} \mathrm{PBS}$ and analyzed using the FC500 flow cytometer.

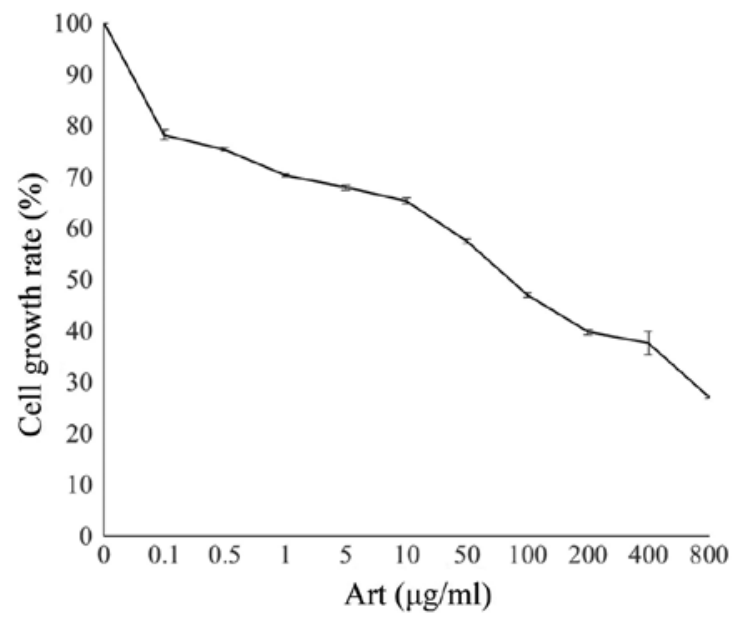

Figure 1. Cell growth rate of A549 lung cancer cells after treatment with various concentrations of Art. A549 lung cancer cells were treated with various concentrations of Art for $24 \mathrm{~h}$ and the cell growth rate was detected by the MTT assay. The cell growth rate was decreased in an Art concentration-dependent manner. Art, artesunate.

Assessment of the expression of Bcl-2 and Bax proteins in A549 cells using FCM. To determine the expression of Bcl-2 and Bax proteins after Art treatment, the harvested cells were fixed overnight in $70 \%$ ice-cold ethanol. After washing with ice-cold PBS, the cells were incubated with anti-Bcl-2 (1:100; cat. no. sc-7382; Santa Cruz Biotechnology, Inc.) and anti-Bax antibodies (1:100; cat. no. sc-20067; Santa Cruz Biotechnology, Inc.) for $30 \mathrm{~min}$ in the dark at room temperature. Subsequently, the cells were incubated with IgG-FITC antibody (1:100; cat. no. 115-095-003; Jackson ImmunoResearch Laboratories, Inc.) for $30 \mathrm{~min}$ in the dark at room temperature. The stained cells were analyzed using the FC500 flow cytometer, with the mean fluorescence intensity representing the expression of Bcl-2 and Bax proteins.

Statistical analysis. Statistical analysis was performed using the SPSS v21 software (IBM Corp.). Values are expressed as the mean \pm standard deviation. Multiple groups were compared using one-way analysis of variance followed by Tukey's test. $\mathrm{P}<0.05$ was considered to indicate a statistically significant difference.

\section{Results}

Art inhibits A549 cell survival and proliferation. An MTT assay was used to determine the viability of A549 lung adenocarcinoma cells treated with different concentrations of Art at a dose range of $0.1-800 \mu \mathrm{g} / \mathrm{ml}$ for $24 \mathrm{~h}$. The survival of A549 cells was decreased by Art in a dose-dependent manner, with a $50 \%$ inhibitory concentration $\left(\mathrm{IC}_{50}\right.$ ) value of $52.87 \pm 2.36 \mu \mathrm{g} / \mathrm{ml}$ (Fig. 1). Treatment with Art exerted a growth inhibitory effect on A549 cells in a concentration-dependent manner.

In addition, FCM revealed that the proliferation index of A549 cells was significantly lower in the Art-treated groups than that in the control group $(\mathrm{P}<0.01)$. The cell proliferation index in the $100 \mu \mathrm{g} / \mathrm{ml}$ group was significantly lower than that in the 25 and $50 \mu \mathrm{g} / \mathrm{ml}$ Art groups $(\mathrm{P}<0.01)$. Furthermore, the cell population in G0/1 phase was significantly higher in 
Table I. Cell cycle phase distribution of A549 cells after treatment with various concentrations of Art.

\begin{tabular}{lcccc}
\hline Group & G0/1 (\%) & $\mathrm{S}(\%)$ & G2/M (\%) & Proliferation index (\%) \\
\hline Control & $59.56 \pm 0.11$ & $36.68 \pm 1.79$ & $3.76 \pm 1.72$ & $40.44 \pm 0.11$ \\
$25 \mu \mathrm{g} / \mathrm{ml} \mathrm{Art}$ & $61.78 \pm 0.19^{\mathrm{a}}$ & $32.10 \pm 3.31$ & $6.12 \pm 3.13$ & $38.22 \pm 0.19^{\mathrm{a}}$ \\
$50 \mu \mathrm{g} / \mathrm{ml} \mathrm{Art}$ & $63.48 \pm 0.18^{\mathrm{a}}$ & $28.41 \pm 1.18^{\mathrm{a}}$ & $8.11 \pm 1.10$ & $36.52 \pm 0.18^{\mathrm{a}}$ \\
$100 \mu \mathrm{g} / \mathrm{ml} \mathrm{Art}$ & $65.32 \pm 0.21^{\mathrm{a}}$ & $23.95 \pm 1.26^{\mathrm{a}}$ & $10.73 \pm 1.08^{\mathrm{a}}$ & $34.68 \pm 0.21^{\mathrm{a}}$ \\
\hline
\end{tabular}

${ }^{a} \mathrm{P}<0.01$ vs. control group. Values are expressed as the mean \pm standard deviation $(\mathrm{n}=3)$. Multiple groups were compared using one-way analysis of variance followed by Tukey's test. Art, artesunate.
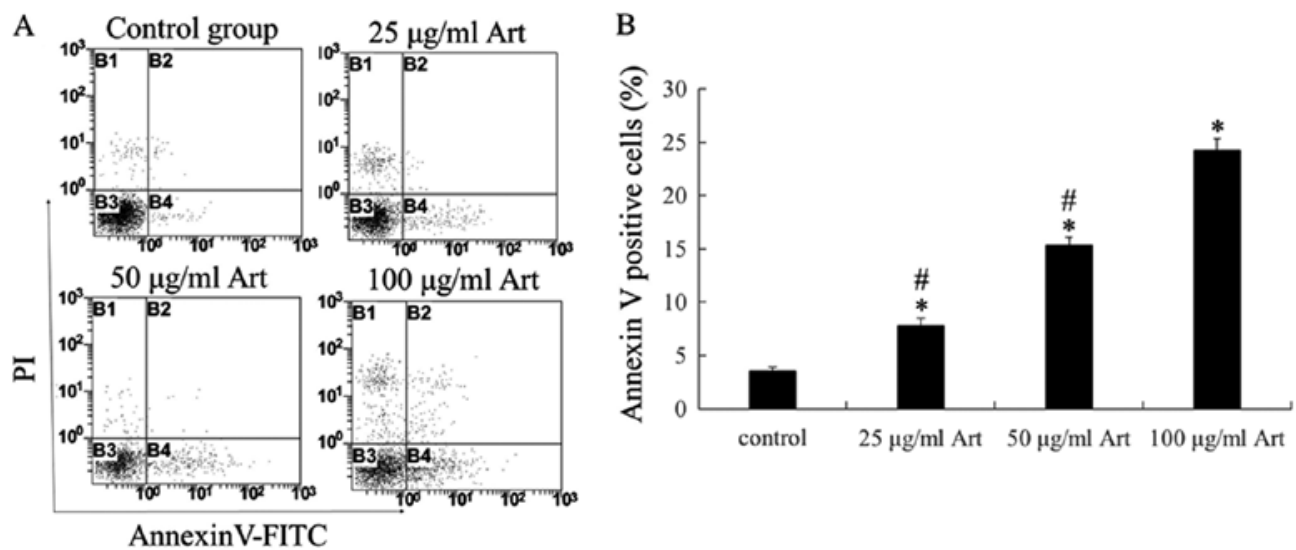

Figure 2. Apoptosis rate of A549 cells after treatment with various concentrations of Art. (A) Representative flow cytometry dot plots with Annexin V-FITC/PI double staining to determine the cell apoptosis rate of A549 cells. (B) Quantitative results for apoptosis of A549 cells calculated as a percentage of the control. The apoptosis rate in the Art-treated groups was significantly higher than that of the control ( $\mathrm{P}<0.01)$. The apoptosis rate in the 25 and $50 \mu \mathrm{g} / \mathrm{ml}$ Art groups was significantly lower than that of the $100 \mu \mathrm{g} / \mathrm{ml}$ group $(\mathrm{P}<0.01) .{ }^{*} \mathrm{P}<0.01$ vs. control group; ${ }^{\#} \mathrm{P}<0.01 \mathrm{vs}$. $100 \mu \mathrm{g} / \mathrm{ml}$ Art group. PI, propidium iodide; Art, artesunate.

the Art-treated groups than in the control and the G0/1 phase population of the cell cycle increased with the concentration of Art $(\mathrm{P}<0.01$; Table I).

Art induces cell apoptosis and modulates the mitochondrial membrane potential. In order to further investigate the mechanism of the decrease in the number of viable A549 cells upon exposure to Art in the MTT assay, Annexin V/PI staining was performed to determine whether apoptosis was induced (Fig. 2). The results indicated that Art triggered apoptosis in a dose-dependent manner within a range of $25-100 \mu \mathrm{g} / \mathrm{ml}$; furthermore, the cell apoptosis rate in the $100 \mu \mathrm{g} / \mathrm{ml}$ Art group was significantly higher than that in the 25 and $50 \mu \mathrm{g} / \mathrm{ml}$ groups $(\mathrm{P}<0.01)$. In addition, the mitochondrial membrane potential was determined in A549 cells using FCM. The mitochondrial membrane potential in the 25, 50 and $100 \mu \mathrm{g} / \mathrm{ml}$ Art groups was significantly lower than that in the control group $(\mathrm{P}<0.01)$. Treatment with Art significantly decreased the mitochondrial membrane potential, suggesting that Art triggered apoptosis in A549 cells in a dose-dependent manner ( $\mathrm{P}<0.01$; Fig. 3$)$.

Art modulates Bcl-2 and Bax protein expression in A549 cells. Bcl-2 and Bax regulate cell apoptosis via pore formation in mitochondrial complexes, thereby serving as markers for further analysis of the mechanism of action of Art in A549 cells. FCM revealed significant downregulation of Bcl-2 protein expression compared with the control $(\mathrm{P}<0.01$; Fig. 4A and B). Furthermore, Bax protein expression was significantly upregulated compared with the control following treatment with Art for $24 \mathrm{~h}(\mathrm{P}<0.01$; Fig. 4C and D). These expression profiles were in line with the increased apoptotic activity via mitochondrial membrane modulation in A549 lung cancer cells after Art treatment.

\section{Discussion}

Lung cancer is one of the most common malignant cancer types worldwide, exhibiting high morbidity and mortality rates (1). Typical treatment regimens include surgery, chemotherapy and radiotherapy $(23,24)$. Chemotherapy is the primary treatment for late-stage, inoperable cases. However, toxic side effects of chemotherapeutic drugs have severely affected the efficacy of such regimens, frequently accounting for treatment failure. Thus, identifying anti-cancer drugs for lung cancer with low toxicity and high efficacy is imperative.

Chinese herbal medicine for tumor treatment has a long history with minimal side effects. Art is a derivative of artemisinin, derived from Artemisia annua, and is a classic 


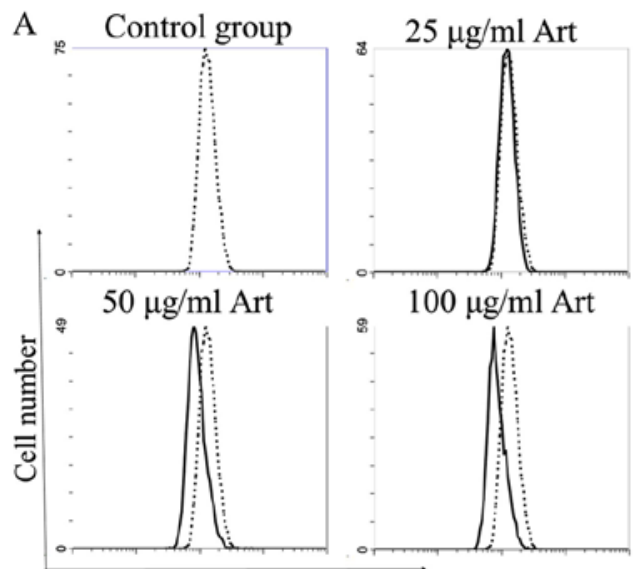

B

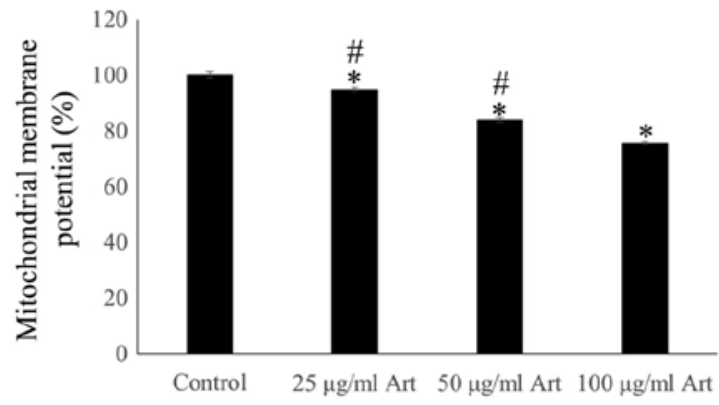

Mitochondrial membrane potential

Figure 3. Mitochondrial membrane potential following Art treatment was detected by flow cytometry. (A) Histograms for the mitochondrial membrane potential in A549 cells treated with different concentrations of Art for $24 \mathrm{~h}$. (B) Quantified results for the mitochondrial membrane potential calculated as a percentage of the control. The mitochondrial membrane potential of A549 cells in the $100 \mu \mathrm{g} / \mathrm{ml}$ Art group was significantly lower than that in the 25 and $50 \mu \mathrm{g} / \mathrm{ml}$ groups $(\mathrm{P}<0.01)$. ${ }^{*} \mathrm{P}<0.01$ vs. control group; ${ }^{*} \mathrm{P}<0.01$ vs. $100 \mu \mathrm{g} / \mathrm{ml}$ Art group. Art, artesunate.

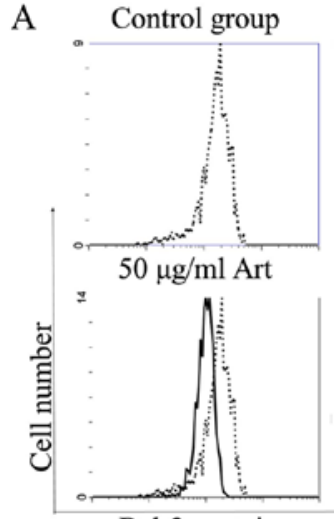

Bcl-2 protein

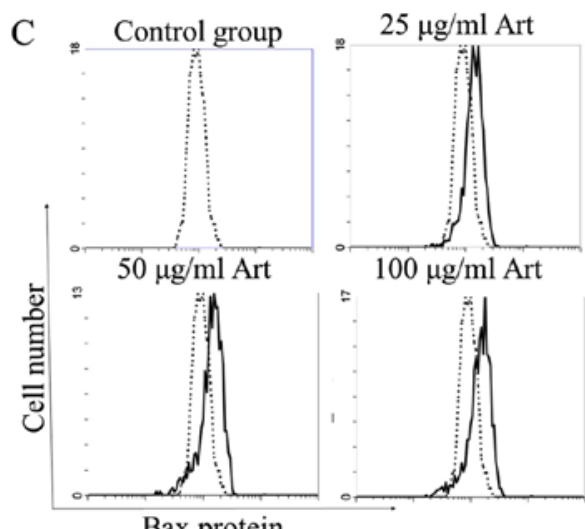

$\mathrm{B}$

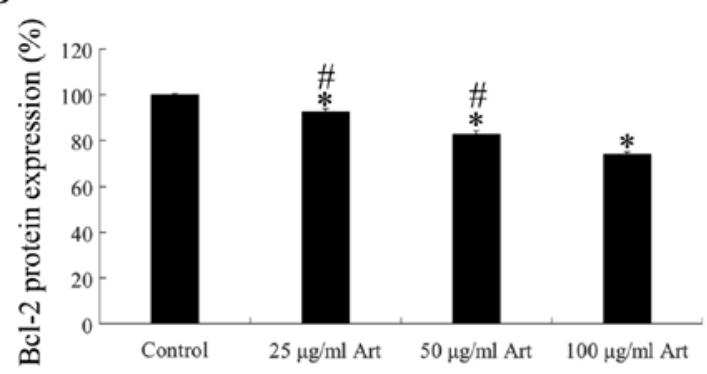

$\mathrm{D}$

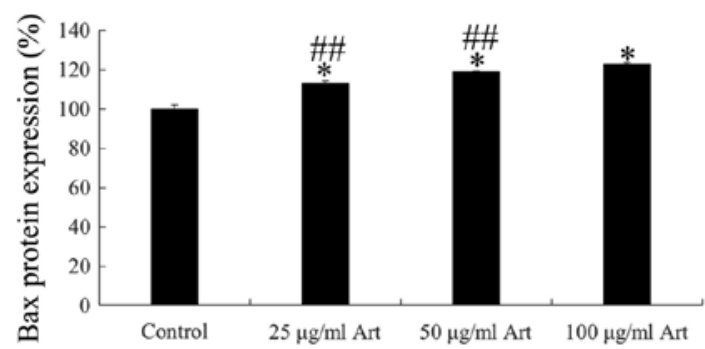

Figure 4. Bcl-2 and Bax protein expression of A549 cells after treatment with Art as detected by FCM. (A) Representative FCM histograms for the detection of Bcl-2 expression in A549 cells treated with Art for $24 \mathrm{~h}$. (B) Quantified levels of Bcl-2 in the different groups calculated as a percentage of the control. Bcl-2 protein expression in A549 cells was significantly lower after Art treatment and the 25 and $50 \mu \mathrm{g} / \mathrm{ml}$ groups exhibited higher expression than the $100 \mu \mathrm{g} / \mathrm{ml}$ group $(\mathrm{P}<0.01)$. (C) Representative FCM histograms for the detection of Bax expression in A549 cells treated with Art for $24 \mathrm{~h}$. (D) Quantified levels of Bax in the different groups calculated as a percentage of the control. Bax protein expression in A549 cells was significantly higher following Art treatment and the 25 and $50 \mu \mathrm{g} / \mathrm{ml}$ cohorts had lower levels than the $100 \mu \mathrm{g} / \mathrm{ml}$ group $(\mathrm{P}<0.05)$. Bax protein expression level was calculated as a percentage of the control. ${ }^{*} \mathrm{P}<0.01$ vs. control group; ${ }^{\#} \mathrm{P}<0.01,{ }^{\# \#} \mathrm{P}<0.05$ vs. $100 \mu \mathrm{g} / \mathrm{ml}$ Art group. FCM, flow cytometry; Art, artesunate.

anti-malarial drug that was recently demonstrated to have anti-tumor activity and is involved in the regulation of immune function (25-29). Several in vitro and in vivo studies have indicated that the anti-tumor effect of Art is associated with the induction of apoptosis and cell cycle arrest. Yang et al (30), reported that Art induces mitochondrial apoptosis of retinoblastoma cells via upregulating Kruppel-like factor 6 in in vivo and in vitro experiments. Wang et al (31), indicated 
that Art inhibited the proliferation and induced ferroptosis of CA-46 cells in vivo. Li et al (32), reported that Art may be valuable as a therapeutic agent for osteoarthritis. Chen et al (33) suggested that Art promoted type I T-helper cell differentiation from $\mathrm{CD}^{+}{ }^{+} \mathrm{T}$ cells by downregulating Sirtuin 1 through microRNA-142, thereby enhancing cell apoptosis in ovarian cancer. Chen et al (34), demonstrated that Art inhibited $\beta$-catenin expression and cell proliferation as well as promoted apoptosis in MG-63 cells, rendering it a promising drug for the clinical treatment of osteosarcoma.

In addition to the anti-tumor effect, Art is also able to reverse the drug resistance of tumors. Nunes et al (35), reported that Art disrupts the androgen receptor antagonist-mediated resistance observed in metastatic castration-resistant prostate cancer. Jing et al (36), suggested that the combination of Art and sorafenib further improved the apoptosis of hepatocellular carcinoma (HCC) and revealed that Art induces HCC apoptosis via PI3K/AKT/mTOR pathway inhibition, thereby suggesting that the combination of Art and sorafenib is a potential therapeutic regimen for advanced HCC.

Previous studies by our group suggested that Art inhibited the growth of esophageal cancer and gastric cancer cells by inducing apoptosis $(22,37,38)$ and reversed the multidrug resistance of esophageal cancer by modulating the expression of ATP binding cassette G2 (37,39). The present study focused on the inhibitory effects of Art in lung cancer. Compared with previous studies $(22,40)$, the present study investigated the inhibitory effects of Art on lung cancer, including apoptosis. In addition, the present study focused on the molecular mechanisms of apoptosis, which was indicated to be mediated by the endogenous apoptosis pathway centered on the mitochondrial membrane potential; furthermore, Art inhibited the growth of lung cancer cells via induction of cell cycle arrest.

In the present study, the lung cancer cell line A549 was selected to test the potential anti-cancer effects and the tumor-suppressive effects of Art against lung cancer cells in vitro. MTT assay suggested that Art inhibited the growth of A549 cells in a dose-dependent manner. The $\mathrm{IC}_{50}$ of Art on the A549 lung cancer cells over $24 \mathrm{~h}$ was $52.87 \mu \mathrm{g} / \mathrm{ml}$ and three concentrations $(25,50$ and $100 \mu \mathrm{g} / \mathrm{ml})$ were selected for subsequent experiments. However, the molecular mechanisms underlying Art-induced cell death in lung cancer cells remained to be clarified. In the present study, it was determined that Art exerts potent cytotoxic effects on the human lung cancer cell line A549 in vitro. The cytotoxicity of Art was mediated by induction of apoptosis and cell cycle arrest, which was further supported by the detection of apoptosis-associated factors.

Malignant tumor cells have strong proliferative abilities, typically with increasing $\mathrm{S}$ and $\mathrm{G}_{2} / \mathrm{M}$ phase populations during the cell cycle. In the present study, it was determined that the proliferation index of A549 lung cancer cells decreased in a dose-dependent manner following Art treatment, which blocked the cell cycle progression of these cells at the G0/1 stage. Thus, these results suggested that Art inhibits the growth of lung cancer cells by inducing cell cycle arrest.

Dysregulation of apoptosis has a critical role in the occurrence and development of tumors and induction of cell apoptosis is vital for drug inhibition in aberrant cell growth. Cellular apoptosis is an automated gene-controlled death mediated via complex regulatory mechanisms. In the present study, cellular apoptosis was determined by the detection of Annexin V/PI staining by FCM. The results suggested that Art induced apoptosis of lung cancer cells in a dose-dependent manner. The mitochondrial membrane potential, Bcl-2 and Bax are essential effectors of the intrinsic pathway of apoptosis, which were modulated by Art treatment. Since the mitochondrial membrane potential is closely associated with apoptosis, the decrease in the level may cause irreversible cell death. Hence, the content of markers of the intrinsic pathway of apoptosis, namely the Bcl-2 and Bax proteins, which regulate the mitochondrial membrane potential, was determined. The expression of Bcl-2 protein was indicated to be significantly decreased along with the upregulation of Bax following Art administration, which was consistent with decreased mitochondrial membrane potential that results in cell apoptosis.

In conclusion, the present study explored the specific mechanisms of lung cancer cell inhibition by Art. Art induced lung cancer cell apoptosis and cell cycle arrest, reduced the level of Bcl-2 protein and mitochondrial membrane potential and increased the expression of Bax protein. A previous study found that Art was associated with minimal toxic side effects (22), taken together with the present findings, it could be speculated that Art may have potential as a highly effective, non-toxic anti-cancer agent in chemotherapy. The molecular mechanisms of growth inhibition of lung cancer cells by Art are complex, necessitating further studies in the future. In future investigations, a variety of lung cancer cell lines should be used to further verify the growth inhibitory effect of Art on lung cancer cells. In addition, non-cancerous cells should be used to determine the side effects of Art.

\section{Acknowledgements}

Not applicable.

\section{Funding}

No funding received.

\section{Availability of data and materials}

The datasets used and/or analyzed during the present study are available from the corresponding author on reasonable request.

\section{Authors' contributions}

YZ performed the experiments and wrote the manuscript. JL performed the experiments and statistical analysis. LL designed the study, performed the experiments and revised the manuscript. All authors read and approved the final version of the manuscript.

\section{Ethics approval and consent to participate}

Not applicable.

\section{Patient consent for publication}

Not applicable. 


\section{Competing interests}

The authors declare that they have no competing interests.

\section{References}

1. de Groot P and Munden RF: Lung cancer epidemiology, risk factors, and prevention. Radiol Clin North Am 50: 863-876, 2012.

2. Kosacka M and Jankowska R: The epidemiology of lung cancer. Pneumonol Alergol Pol 75: 76-80, 2007 (In Polish).

3. Radziszewska A,Karczmarek-BorowskaB,Gradalska-LampartM and Filip AA: Epidemiology, prevention and risk morbidity factors for lung cancer. Pol Merkur Lekarski 38: 113-118, 2015 (In Polish)

4. Steliga MA and Dresler CM: Epidemiology of lung cancer: Smoking, secondhand smoke, and genetics. Surg Oncol Clin N Am 20: 605-618, 2011.

5. Tabchi S, Kassouf E, Rassy EE, Kourie HR, Martin J, Campeau MP, Tehfe M and Blais N: Management of stage III non-small cell lung cancer. Semin Oncol 44: 163-177, 2017.

6. Abuaku BK, Mensah BA, Ofori MF, Myers-Hansen J, Derkyi-Kwarteng AN, Essilfie F, Dokurugu M, Amoakoh E, Koram KA and Ghansah A: Efficacy of artesunate/amodiaquine in the treatment of uncomplicated malaria among children in Ghana. Am J Trop Med Hyg 97: 690-695, 2017.

7. Roussel C, Caumes E, Thellier M, Ndour PA, Buffet PA and Jaureguiberry S: Artesunate to treat severe malaria in travellers: review of efficacy and safety and practical implications. J Travel Med: doi:10.1093/jtm/taw093.

8. Jauréguiberry S, Thellier M, Ndour PA, Ader F, Roussel C, Sonneville R, Mayaux J, Matheron S, Angoulvant A, Wyplosz B, et al French Artesunate Working Group: Delayed-onset hemolytic anemia in patients with travel-associated severe malaria treated with artesunate, France, 2011-2013. Emerg Infect Dis 21: 804-812, 2015.

9. Raffray L, Receveur MC, Beguet M, Lauroua P, Pistone T and Malvy D: Severe delayed autoimmune haemolytic anaemia following artesunate administration in severe malaria: A case report. Malar J 13: 398, 2014

10. Rolling T, Agbenyega T, Krishna S, Kremsner PG and Cramer JP: Delayed haemolysis after artesunate treatment of severe malaria - review of the literature and perspective. Travel Med Infect Dis 13: $143-149,2015$.

11. Greenshields AL,Fernando W and Hoskin DW: The anti-malarial drug artesunate causes cell cycle arrest and apoptosis of triple-negative MDA-MB-468 and HER2-enriched SK-BR-3 breast cancer cells. Exp Mol Pathol 107: 10-22, 2019.

12. Wang N, Chen H, Teng Y, Ding X, Wu H and Jin X: Artesunate inhibits proliferation and invasion of mouse hemangioendothelioma cells in vitro and of tumor growth in vivo. Oncol Lett 14 6170-6176, 2017

13. Zheng L and Pan J: The anti-malarial drug artesunate blocks $\mathrm{Wnt} / \beta$-catenin pathway and inhibits growth, migration and invasion of uveal melanoma cells. Curr Cancer Drug Targets 18: 988-998, 2018.

14. Verma S, Das P and Kumar VL: Chemoprevention by artesunate in a preclinical model of colorectal cancer involves down regulation of $\beta$-catenin, suppression of angiogenesis, cellular proliferation and induction of apoptosis. Chem Biol Interact 278: 84-91, 2017.

15. Vandewynckel YP, Laukens D, Geerts A, Vanhove C, Descamps B, Colle I, Devisscher L, Bogaerts E, Paridaens A, Verhelst X, et al: Therapeutic effects of artesunate in hepatocellular carcinoma: Repurposing an ancient antimalarial agent. Eur J Gastroenterol Hepatol 26: 861-870, 2014.

16. Jeong DE, Song HJ, Lim S, Lee SJ, Lim JE, Nam DH, Joo KM, Jeong BC, Jeon SS, Choi HY, et al: Repurposing the anti-malarial drug artesunate as a novel therapeutic agent for metastatic renal cell carcinoma due to its attenuation of tumor growth, metastasis, and angiogenesis. Oncotarget 6: 33046-33064, 2015.

17. Kim C, Lee JH, Kim SH, Sethi G and Ahn KS: Artesunate suppresses tumor growth and induces apoptosis through the modulation of multiple oncogenic cascades in a chronic myeloid leukemia xenograft mouse model. Oncotarget 6: 4020-4035, 2015.

18. Rasheed SA, Efferth T, Asangani IA and Allgayer H: First evidence that the antimalarial drug artesunate inhibits invasion and in vivo metastasis in lung cancer by targeting essential extracellular proteases. Int J Cancer 127: 1475-1485, 2010.
19. Zhang L, Qian H, Sha M, Luan Z, Lin M, Yuan D, Li X, Huang J and Ye L: Downregulation of HOTAIR expression mediated anti-metastatic effect of artesunate on cervical cancer by inhibiting COX-2 expression. PLoS One 11: e0164838, 2016.

20. Alenzi FQ: Links between apoptosis, proliferation and the cell cycle. Br J Biomed Sci 61: 99-102, 2004.

21. Cvejic D, Selemetjev S, Savin S, Paunovic I and Tatic S: Changes in the balance between proliferation and apoptosis during the progression of malignancy in thyroid tumours. Eur J Histochem 53: 65-71, 2009.

22. Liu L, Zuo LF, Zuo J and Wang J: Artesunate induces apoptosis and inhibits growth of Eca109 and Ec9706 human esophageal cancer cell lines in vitro and in vivo. Mol Med Rep 12: 1465-1472, 2015.

23. Duma N, Santana-Davila R and Molina JR: Non-small cell lung cancer: Epidemiology, screening, diagnosis, and treatment. Mayo Clin Proc 94: 1623-1640, 2019.

24. Hirsch FR, Scagliotti GV, Mulshine JL, Kwon R, Curran WJ Jr, Wu YL and Paz-Ares L: Lung cancer: Current therapies and new targeted treatments. Lancet 389: 299-311, 2017.

25. von Hagens C, Walter-Sack I, Goeckenjan M, Osburg J, Storch-Hagenlocher B, Sertel S, Elsässer M, Remppis BA, Edler L, Munzinger J, et al: Prospective open uncontrolled phase I study to define a well-tolerated dose of oral artesunate as add-on therapy in patients with metastatic breast cancer (ARTIC M33/2). Breast Cancer Res Treat 164: 359-369, 2017.

26. Wang Z, Wang C, Wu Z, Xue J, Shen B, Zuo W, Wang Z and Wang SL: Artesunate suppresses the growth of prostatic cancer cells through inhibiting androgen receptor. Biol Pharm Bull 40: 479-485, 2017.

27. Li Q, Ni W, Deng Z, Liu M, She L and Xie Q: Targeting nasopharyngeal carcinoma by artesunate through inhibiting Akt/mTOR and inducing oxidative stress. Fundam Clin Pharmacol 31:301-310, 2017.

28. Cui C, Feng H, Shi X, Wang Y, Feng Z, Liu J, Han Z, Fu J, Fu Z and Tong H: Artesunate down-regulates immunosuppression from colorectal cancer Colon 26 and RKO cells in vitro by decreasing transforming growth factor $\beta 1$ and interleukin-10. Int Immunopharmacol 27: 110-121, 2015.

29. Rassias DJ and Weathers PJ: Dried leaf Artemisia annua efficacy against non-small cell lung cancer. Phytomedicine 52: 247-253, 2019.

30. Yang Y, Wu N, Wu Y, Chen H, Qiu J, Qian X, Zeng J, Chiu K, Gao Q and Zhuang J: Artesunate induces mitochondria-mediated apoptosis of human retinoblastoma cells by upregulating Kruppel-like factor 6. Cell Death Dis 10: 862, 2019.

31. Wang N, Zeng GZ, Yin JL and Bian ZX: Artesunate activates the ATF4-CHOP-CHAC1 pathway and affects ferroptosis in Burkitt's lymphoma. Biochem Biophys Res Commun 519: 533-539, 2019.

32. Li Y, Mu W, Ren J, Wuermanbieke S, Wahafu T, Ji B, Ma H, Amat A, Zhang K and Cao L: Artesunate alleviates interleukin-1 $\beta$-induced inflammatory response and apoptosis by inhibiting the NF- $x \mathrm{~B}$ signaling pathway in chondrocyte-like ATDC5 cells, and delays the progression of osteoarthritis in a mouse model. Int J Mol Med 44: 1541-1551, 2019.

33. Chen X, Zhang XL, Zhang GH and Gao YF: Artesunate promotes Th1 differentiation from CD4+ T cells to enhance cell apoptosis in ovarian cancer via miR-142. Braz J Med Biol Res 52: e7992, 2019.

34. Chen P, Gu WL, Gong MZ, Wang J and Li DQ: Artesunate decreases beta-catenin expression, cell proliferation and apoptosis resistance in the MG-63 human osteosarcoma cell line. Cell Physiol Biochem 43: 1939-1949, 2017.

35. Nunes JJ, Pandey SK, Yadav A, Goel S and Ateeq B: Targeting NF-kappa B signaling by artesunate restores sensitivity of castrate-resistant prostate cancer cells to antiandrogens. Neoplasia 19: 333-345, 2017.

36. Jing W, Shuo L, Yingru X, Min M, Runpeng Z, Jun X and Dong H: Artesunate promotes sensitivity to sorafenib in hepatocellular carcinoma. Biochem Biophys Res Commun 519: 41-45, 2019.

37. Liu L, Zuo LF and Guo JW: Reversal of multidrug resistance by the anti-malaria drug artesunate in the esophageal cancer Eca109/ABCG2 cell line. Oncol Lett 6: 1475-1481, 2013.

38. Wang L, Liu L, Wang J and Chen Y: Inhibitory effect of artesunate on growth and apoptosis of gastric cancer cells. Arch Med Res 48: 623-630, 2017.

39. Wang L, Liu L, Chen Y, Du Y, Wang J and Liu J: Correlation between adenosine triphosphate (ATP)-binding cassette transporter G2 (ABCG2) and drug resistance of esophageal cancer and reversal of drug resistance by artesunate. Pathol Res Pract 214: 1467-1473, 2018 .

40. Zhang P, Luo HS, Li M and Tan SY: Artesunate inhibits the growth and induces apoptosis of human gastric cancer cells by downregulating COX-2. OncoTargets Ther 8: 845-854, 2015. 